\title{
Sustainable Entrepreneurship in the Dutch Construction Industry
}

\section{Rosalinde J.A. Klein Woolthuis ${ }^{1,2}$}

1 Department of Management and Organisation, Faculty of Economics and Business Administration, VU University Amsterdam, De Boelelaan 1105, 1081 HV, Amsterdam, The Netherlands; E-Mail: rkleinwoolthuis@yahoo.com; Tel.: +31-20-778-4201; Fax: +31-20-598-6151.

2 TNO Built Environment and Geosciences, Van Mourik Broekmanweg 6, 2628 XE, Delft, The Netherlands

Received: 1 December 2009 / Accepted: 22 January 2010 / Published: 4 February 2010

\begin{abstract}
This article discusses the strategies that sustainable entrepreneurs use to interact with their environment in the Dutch construction industry. The Dutch construction industry is under great pressure to move towards sustainability, and entrepreneurs are believed to be able to play a large role in this transition by introducing new products and new business practices. But how can entrepreneurs prosper in an environment that is not geared up towards such a change? And which strategies do they use to bend conditions in their favor? In this article we make use of the Market and System Failure Framework to analyze the pressures that entrepreneurs are confronted with when introducing sustainable innovations. We recognize that these pressures can be seen as bottlenecks, but that market and system failures can also create entrepreneurial opportunities. We interviewed 16 entrepreneurs in the Dutch construction industry to determine the influences they experienced from their environment and the strategies they use to deal with these. We conclude that we can distinguish between system building and following entrepreneurs, where the former aims to build a new system to challenge the old one, whereas the latter rather makes use of existing structures to build a business. We find that both strategies can be successful and that overall, the entrepreneurs confirm the belief that sustainability on people, planet and transparency aspects, can contribute very well to the long term profitability of the businesses the entrepreneurs are running. These in-depth insights into the influences from the context on the one hand, and the entrepreneurs' strategic reactions on the other hand, contribute to our understanding of the interactions between entrepreneurs and the system
\end{abstract}


context. This can help us to more effectively stimulate and support innovating entrepreneurs to contribute to the transition towards sustainability.

Keywords: entrepreneurship; innovation systems; transitions; sustainability; construction sector

\section{Introduction}

Society increasingly imposes a challenge for changing the nature of economic activities in almost every sector of the economy. This structural, long-term reorientation and transformation of economic activities is termed a transition [1,2]. In the building environment such a transition is desirable for two reasons. First this is because the construction sector is a big user of energy and materials, and creates much waste. The construction of buildings consumes annually $25 \%$ of the virgin wood and $40 \%$ of the raw stone, gravel and sand [3]. Globally buildings consume $16 \%$ of the water and indirectly produce nearly $70 \%$ of all sulphur oxides [4]. The second reason to focus on the construction sector is because construction industries are not 'footloose', hence, all progress that is made in improving the sustainability performance of the construction industry benefits the regions and countries they operate in, while at the same time knowledge and experience can be built up that can be sold internationally to strengthen the competitive position of the industry.

Whereas this holds true for construction in general, there are also specific characteristics of the Dutch construction industry that push the sector towards more sustainable practices. The Dutch construction sector is of considerable importance to the Dutch economy. As of January 2009, the construction sector in the Netherlands consisted of almost 110,000 companies. This number has grown with $40 \%$ over the years 2006-2009. This increase has mainly been due to one-person businesses (which comprised $70 \%$ of the sector in 2009) which are expected to disappear again in current, difficult times due to the financial crisis. The sector contributes about $7 \%$ of GDP and provides $7 \%$ of total employment (CBS, 2009).

Since 2001, when fraudulent industry practices came to the light and led to nation-wide investigations, there has been strict regulation and monitoring of the sector. Next to these strict regulative pressures focusing on price fixing and colluding practices, the environmental regulations have tightened. All together, the industry is being pushed towards sustainability, a functioning of the industry that 'meets the needs of the present without compromising the ability of future generations to meet their own needs' [5]. This concept of sustainability encompasses the 'triple bottom line', since it considers an integration of impacts in economic, environmental and social terms. We also define it as including transparency as this is an important condition for well functioning markets and for ethical business. For the industry this means more attention to the environmental aspects of the building process and use of buildings (planet), greater transparency and attention to the ethical aspects of their operations (transparency), attention to safety and training of employees (people) and on reviving healthy competition (profit). For restructuring the sector into a healthy and competitive industry again, an important role was envisaged for sustainable innovation by stimulating trust and collaboration, supply chain integration and providing funding for such initiatives in e.g., platforms such as KSI 
(Knowledge Network System Innovation) and PSIB (Platform System Innovation in the Construction Industry) and subsidy schemes as executed by Senter Novem [6]. It also means that we need changes that go beyond incremental innovations based on technical change only [7]. Sustainable innovations are characterized by new combinations that integrate all three aspects of sustainability and that have the potential to contribute to the transition by changing a sector towards a more sustainable state [8].This goes beyond the old perspective that innovations can only contribute to sustainability with an inherent trade-off to economic profitability [9]. It is assumed that entrepreneurs play an important role in shaping these new landscapes [2] as they are venturesome people that are willing and able to experiment with innovations and that have the initiative and persistence to make change happen [10]. These 'Schumpeterian entrepreneurs' are able to overthrow and change the current structures around them and force the innovation process into new directions by shaping a new path towards renewal of the sector $[7,11,12]$. Due to their ability to spawn variety and experiment with innovations in terms of new technologies and new organizational forms, entrepreneurs are thought to be in the right position to combine a contribution to the transition towards sustainability with an increase in economic competitiveness through the generation of value-adding sustainable innovations.

However, entrepreneurs are bound by the context in which they operate. Introducing and diffusing sustainable innovations necessitates far-reaching changes in the structure and organization of the entire system context. Entrepreneurs are influenced by its policies, regulations, interactions, norms, societal pressures etc. [13]. In the institutional theory literature this is described as a 'field' [14] whereas in the innovation systems literature it is referred to as an innovation system. When the sustainable innovations that entrepreneurs aim to introduce challenge the status quo in such a field, conflicts may arise with the established actors in the field and the institutional standards (routines, structures). Institutional entrepreneurs, i.e., entrepreneurs that by the nature of their actions, or introduction of products or services have the goal or potential to change the existing institutions and structures, must hence deploy strategies that not only focus on their business, but also on the active changing of the context that enables their business to take off. In this study we focus on such entrepreneurs that aim to introduce sustainable products and technologies to increase the sustainability of the Dutch construction sector.

The emergence of innovations does not take place in a vacuum, but rather occurs through a dynamic interplay between various actors such as firms, universities and government bodies [13]. This is the central idea behind the Innovation System approach, which views innovation as the result of the interactions in an innovation system consisting of all actors and institutions that affect both the rate and direction of innovation in society [15]. The Innovation System approach emphasizes that innovation is both an individual and a collective act, resulting from interactions and coordination between several firms and organizations rather than from the independent actions of single dominant firms [10,16].

Individual firms and entrepreneurs are the micro-level of an innovation system, but they act within the larger context of the innovation system on macro-level [17]. Various factors within the innovation system could exert a pressure on entrepreneurs on the micro-level, such as interdependencies with multiple stakeholders, processes of competition and cooperation, governmental policies, regulations, societal norms, values etc. These influences from the system context can be both an enabler and a constraint for sustainable entrepreneurial action [18]. Influences from the system context that enable 
and stimulate sustainable innovation, could be explanatory factors for why in some settings entrepreneurs are able and willing to develop sustainable innovations while in other situations they are not.

Figure 1. Entrepreneurs, their networks, and the system context.

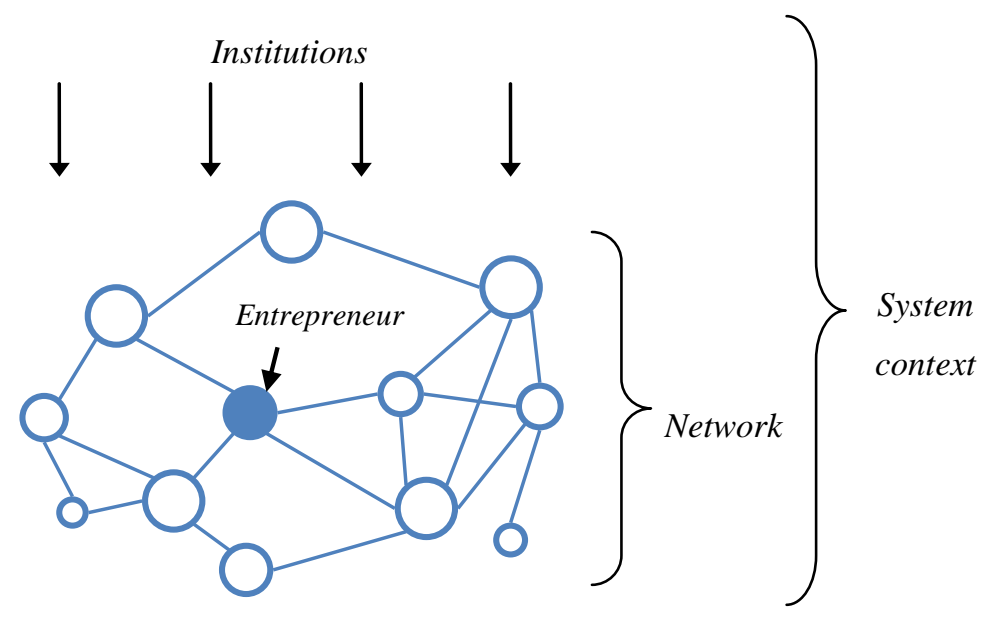

For the analysis of the system in which the entrepreneur operates, we built upon the System Failure Framework as introduced by Klein Woolthuis et al. [19]. Additions include further elaboration on institutions to include insights from institutional theory into the framework, and inclusion of market structure as market failures are an important reason for lack of innovation and entrepreneurship and form an important rationale for policy interventions. We let the research question guide the delineation of the system. In this article where we look at sustainable building, the system includes all actors and system interactions that influence sustainable building, i.e., builders, installers, entrepreneurs, city planners, governments agencies etc. and the interactions among them that shape the 'rules' of the game.

We describe the system failures on the basis of Klein Woolthuis et al. [19] who distinguish between:

1. Infrastructure: The enabling structures that make economic activities possible. Examples are roads, railways, IT infrastructure etc. Absence of these would hinder innovation (an economic activity in general).

2. Institutions: Hard institutions referring the rules and regulations set by regulators. There are hard in the sense that they are explicit, specific and enforceable. Absence of well functioning formal institutions (i.e., absence of contract law or IP protection) hinders innovation, but too rigid formal institutions may have the same effect (i.e., bureaucracy). Soft institutions refer to the implicit 'rules of the game', the norms, values, cultures that implicitly shape actors preferences, interpretations and consequent behaviors. Informal 'rules' can stimulate innovation if they value creativity and change, whereas the opposite is true if the consensus tends towards keeping things as they are. 
3. Interaction: Hard network failure referring to too much interaction between parties that know each other well and for a long time (strong ties) leading to 'lock in' and blind spots. Weak network failure referring to too little interaction between parties, or absence of linkages all together which hinders innovation as parties do not know each other (well enough) and will hence not engage in knowledge exchange, learning and/or collaboration.

4. Capabilities: Referring to the knowledge and know-how that actors have in house to engage in innovation. This includes the technological and/or technical knowledge and know-how to for instance develop a new product successfully, but also to the organizational and marketing skills that are required to manage the innovation process and the successful introduction of a product or process into the market.

For the analysis in this paper we add the following market characteristics that may hinder innovation:

5. Market demand: Characteristic of the introduction of new products and processes is that the rate of adoption can be very slow in the beginning. As a result economics of scale cannot be achieved and costs remain high. The innovator will need the market to become sufficiently large to overcome this problem (demand quantity). To get to the stage where products or processes can be 'produced' in larger quantities, the 'child diseases' have to be discovered and restored to make a large 'role out' possible. For this, lead users or lead markets are needed that demand a high quality (demand quality) which stimulates parties to innovate and seek the cutting edge in new technologies. The government can play an important role here in public procurement or setting standards to increase the requirements for products and processes.

6. Market structure: Market power and entry barriers: The market structure mainly determines the openness of the market to new players, new products and processes, or in other words, the degree to which the market is dominated by a limited amount of actors that can effectively determine (or influence) the quantity and prices of the goods available in that market (market dominance, varying from monopoly (single actor) to oligopoly (small group of suppliers), monopsomy (small group of buyers) and cartels (collaborative agreements on prices and competition). This is referred to as market power. Entry barriers can have a similar effect on innovation and entrepreneurship when high initial costs, e.g., for knowledge development or setting up capital intensive production or research facilities (sunk costs) hinder entry into a field or market.

7. Externalities: Positive or negative externalities may corrupt the incentives for innovation when the market price does not account for the external effects of an economic activity on other individuals and/or the environment. Pollution is the classical example of negative externalities. Positive externalities might also hinder innovation though, if actor A invests in e.g., more energy efficient buildings and actor B benefits from this investment without A having the possibility to earn back its investment. This problem is often referred to as the issue of split incentives, which can occur in

a. the value chain: investments and benefits lie with different actors in the value chain, e.g., energy efficient building where the end-user benefits from low energy bills without sharing the investment, 
b. time: benefits and/or costs resulting from an investment are delayed in time, e.g., the costs of the demolition of a building is not carried by the builder,

c. place: the costs and benefits are split geographically, e.g., environmentally hazardous ships are sailed to third world countries to be demolished there where there are less stringent environmental and labor laws.

In all these cases, the direct relation between cause and consequence is lost and hence market incentives for innovation or sustainability are dampened. To deal with such issues, market regulation is of great importance, as it increases transparency for buyers to be able to decide not only on price, but also on the process that led to the price (fairness). These aspects are at the core of sustainability issues as the reason behind unsustainable practices is often the lack of 'total cost' approaches, the lack of transparency, and the 'footloose' nature of international business which factors open up the possibility for actors to use the principle of externalities to their advantage, i.e., reaping benefits without carrying the full costs of their actions.

Table 1. Market and system failure framework.

\begin{tabular}{|c|c|c|c|c|c|c|}
\hline \multicolumn{2}{|c|}{$\begin{array}{l}\text { Market \& } \\
\text { System } \\
\text { characteristics }\end{array}$} & $\begin{array}{c}\text { Users } \\
\text { (consumers, } \\
\text { companies, lead } \\
\text { clients i.e., } \\
\text { government) }\end{array}$ & $\begin{array}{c}\text { Producers } \\
\text { (MNEs, SMEs, } \\
\text { entrepreneurs) }\end{array}$ & $\begin{array}{c}\text { Knowledge } \\
\text { providers } \\
\text { (Universities, } \\
\text { research } \\
\text { institutes) } \\
\end{array}$ & $\begin{array}{c}\text { Specialist } \\
\text { service } \\
\text { providers } \\
\text { (Consultant, } \\
\text { banks, VC) } \\
\end{array}$ & $\begin{array}{l}\text { Government } \\
\text { (regulator, } \\
\text { national, } \\
\text { local) }\end{array}$ \\
\hline \multicolumn{7}{|l|}{ Infrastructure } \\
\hline \multirow{2}{*}{ Institutions } & Hard & & & & & \\
\hline & Soft & & & & & \\
\hline \multirow{2}{*}{ Interaction } & $\begin{array}{l}\text { Hard network } \\
\text { failure }\end{array}$ & & & & & \\
\hline & $\begin{array}{l}\text { Soft network } \\
\text { failure }\end{array}$ & & & & & \\
\hline \multirow[b]{2}{*}{ Capabilities } & Technological & & & & & \\
\hline & $\begin{array}{l}\text { Organizational/ } \\
\text { Marketing }\end{array}$ & & & & & \\
\hline \multirow{2}{*}{$\begin{array}{l}\text { Market } \\
\text { demand }\end{array}$} & Quantity & & & & & \\
\hline & Quality & & & & & \\
\hline \multirow{2}{*}{$\begin{array}{l}\text { Market } \\
\text { structure }\end{array}$} & Market power & & & & & \\
\hline & Entry barriers & & & & & \\
\hline \multirow{2}{*}{ Externalities } & Split incentives & & & & & \\
\hline & Transparency & & & & & \\
\hline
\end{tabular}

In this research we focus on a specific sub-category of the institutional entrepreneurs being the sustainable entrepreneurs which we define as actors that want to reconcile economic growth with a contribution to sustainability in their business model. As argued earlier, this might lead to 'clashes' with the existing market and system characteristics, and hence entrepreneurs have to find ways to deal with the pressures resulting from this confrontation. In the literature, a distinction has been made between response strategies according to the level of resistance to the institutional pressures of a 
system [20] or to the level of pro-activeness [21]. On the basis of our interviews we recognized that, due to their convictions on their role in the system, entrepreneurs could be categorized as system following or system building. In other words, they can not only accept or resist pressures from their environment, they can also actively try to influence and thereby co-create the conditions in which they operate. We introduce this distinction here as we will discuss the results of our interviews according to this classification. We recognize that a system following strategy is deployed by entrepreneurs that adapt current practices to comply with regulations or to enhance profitability by using end-of-pipe control measures which results in incremental reduction of their environmental impact. On the other end of the spectrum, we distinguish a system building strategy that is followed by entrepreneurs that are continuously improving the sustainability of their business, by anticipating to future regulations, social trends and building resources, interacting with social conditions and creating value, beyond what is legally required or accepted as standard practice [21-23]. System building entrepreneurial strategies are more likely to occur when the institutional context pushes firms towards more voluntary attention to sustainability, but are less likely to occur when the business environment is complex and uncertain since this makes it harder for entrepreneurs to recognize social issues [21].

\section{Method}

To examine the interaction between entrepreneurs and their environment, and the strategies they use to co-create this context, we choose to search for entrepreneurs that met the following criteria: (1) they are entrepreneurs that create new economic activity leading to change in the marketplace, (2) they innovate, i.e., successful experimentation, development and introduction of new products, processes, combinations, services or organizational forms, (3) they contribute towards sustainability, i.e., they have the ability to be scaled up to change or replace current practices in the sector which results in reduced deterioration of the human environment and/or of natural resources while at the same time retained or improved economic competitiveness, and (4) they belong to the sector, i.e., they are suppliers of innovations (based on various technologies) to the construction industry in The Netherlands (most of them active in the installation of equipment to produce, save or manage energy in houses and buildings).

On the basis of these criteria 16 entrepreneurs that were active in the field of sustainable energy production, distribution and management in the Dutch construction industry were selected. This industry includes residential buildings, such as houses and apartment complexes, as well as utilities buildings, such as commercial, industrial or governmental buildings. Amongst the group, differences that occurred were mainly the size of the company, varying from about five people to over a hundred, and the phase in the life-cycle the companies were in, varying from fresh start-ups to more established companies in their growth phase (see Table 2).

We have chosen a qualitative research method because this research aims to investigate a 'how' question which demands qualitative way of research offering the necessary flexibility to appropriately investigate the strategies of entrepreneurs and the causal relations underlying them [24]. In the summer of 2009 we conducted face to face interviews making use of open interviews asking the entrepreneurs (1) which influences they experience from their environment and (2) which strategies they consciously use to influence their environment to (a) sell their products/services, and (b) change 
their environment as to create more favorable conditions for their businesses (e.g., greater environmental awareness). The interviews all lasted around 1.5 hours and were transcribed. The transcripts were sent to the respondents for comments. All interviews were held with the entrepreneurs themselves: the people within the entrepreneurial companies who are able to explain the rationales behind the strategy of the entrepreneurial undertaking - in most cases this was the founder and CEO of the company. These are the experts on the questions in this research and are best able to report how they experienced influences from the system and how they react and contribute to it.

Table 2. Description of the interviewed entrepreneurs.

\begin{tabular}{|c|c|l|}
\hline $\begin{array}{c}\text { Reference } \\
\text { number }\end{array}$ & $\begin{array}{c}\text { Phase in life } \\
\text { cycle }\end{array}$ & \multicolumn{1}{|c|}{$\begin{array}{c}\text { Technology they are bringing to market for sustainable } \\
\text { innovation }\end{array}$} \\
\hline 1 & Start-up & Photo-voltaics with solar thermal \\
\hline 2 & Growth & Photo-voltaics, solar thermal, urban wind power and biomass \\
\hline 3 & Start-up & Photo-voltaics \\
\hline 4 & Maturity & Heat collection and storage \\
\hline 5 & Start-up & Solar thermal and water power \\
\hline 6 & Growth & Solar thermal, wind, heat pump and storage \\
\hline 7 & Start-up & Urban biowaste \\
\hline 8 & Growth & Photo-voltaics \\
\hline 9 & Start-up & Electricity and electronics \\
\hline 10 & Start-up & Urban wind power \\
\hline 11 & Growth & Climate systems and electronics \\
\hline 12 & Growth & Electricity, wireless electronics \\
\hline 13 & Growth & Wind, solar thermal, photo-voltaics and heat storage \\
\hline 14 & Growth & Heat exchange \\
\hline 15 & Start-up & Solar thermal \\
\hline 16 & Start-up & Mechanics and photo-voltaics \\
\hline
\end{tabular}

Because open interviews were used, we did not get information on all aspects of the theoretical framework. Especially the more complex conceptual concepts as externalities, and the more taken for granted aspects such as the presence of good infrastructures and a given market structure, were not addressed by choosing this method. We chose this approach despite these drawbacks as we wanted to get insight into the issues that were most clearly 'on the entrepreneurs' radar' and how entrepreneurs, in their day-to-day work, deal with systemic drivers and bottlenecks; do they turn them into threats or opportunities? And how do they do so?

Another reason for not covering all aspects of the theoretical framework in the interviews was time restriction as it would take up too much time go through all. This would hence lead to very superficial answers. We hence sacrificed completeness for more in-depth insight into experienced bottlenecks and drivers for sustainable innovations. As an outcome of the interviews we could classify the entrepreneurs in either system following or system building. We ended up categorizing eight entrepreneurs as system building, and eight as system following. That this split was 50/50 was a coincidence. Also, the difference between the system following and building entrepreneurs, was not always as clear cut as theory would suggest: system builders do not want to change everything, they 
also have to choose 'their battles'. At the same time system followers are not 'lame ducks', but also strategically work out those aspects they can, or cannot change.

We give a brief sketch of the type of entrepreneurs we have interviewed. The numbers in the text refer to the entrepreneur as mentioned in the table above. Eleven out of 16 interviewed entrepreneurs are driven by idealism. One phrases it as: 'I want to contribute to the sustainability of this world' (1). However, commercial motives are equally important: 'Idealistic motives are helpful at the start, but in order to be successful and to make an impact business sense is crucial' (10). We observe that the entrepreneurs that emphasize business skills most (6 out of 16) also seem to show faster growth than those that emphasize idealistic motives.

All entrepreneurs are convinced of the economic viability of the triple bottom line: 'we make profit by fully focusing on sustainability and hence we do not consider upfront investments problematic' (6). Their vision on the future is clear and focused on the long term. They also want their company or innovation to be an important building block of that future. Thirteen out of the 16 entrepreneurs want to fundamentally change energy production, use and management in the construction industry. However, they are aware there still is a long way to go: 'we have to fundamentally change the structure of the sector and transform the lifestyles of people' (9). All entrepreneurs thereby acknowledge that their innovation cannot become successful in the current system's status quo, and hence they emphasize the need for change to increase the potential for sustainable innovations. All but one of the respondents believe that the future state of the system will include a decentralized two-way electricity grid, and many of their companies depend on this.

In the next section we will discuss the result from our empirical study into the strategies of 16 entrepreneurs in the Dutch construction industry and look at (1) which pressures they experience from their context, categorized into the system and market characteristics, and (2) which strategy they employ to deal with these pressures, the system following or system building strategy.

Figure 2. The research model—Context influences and entrepreneurial strategies.

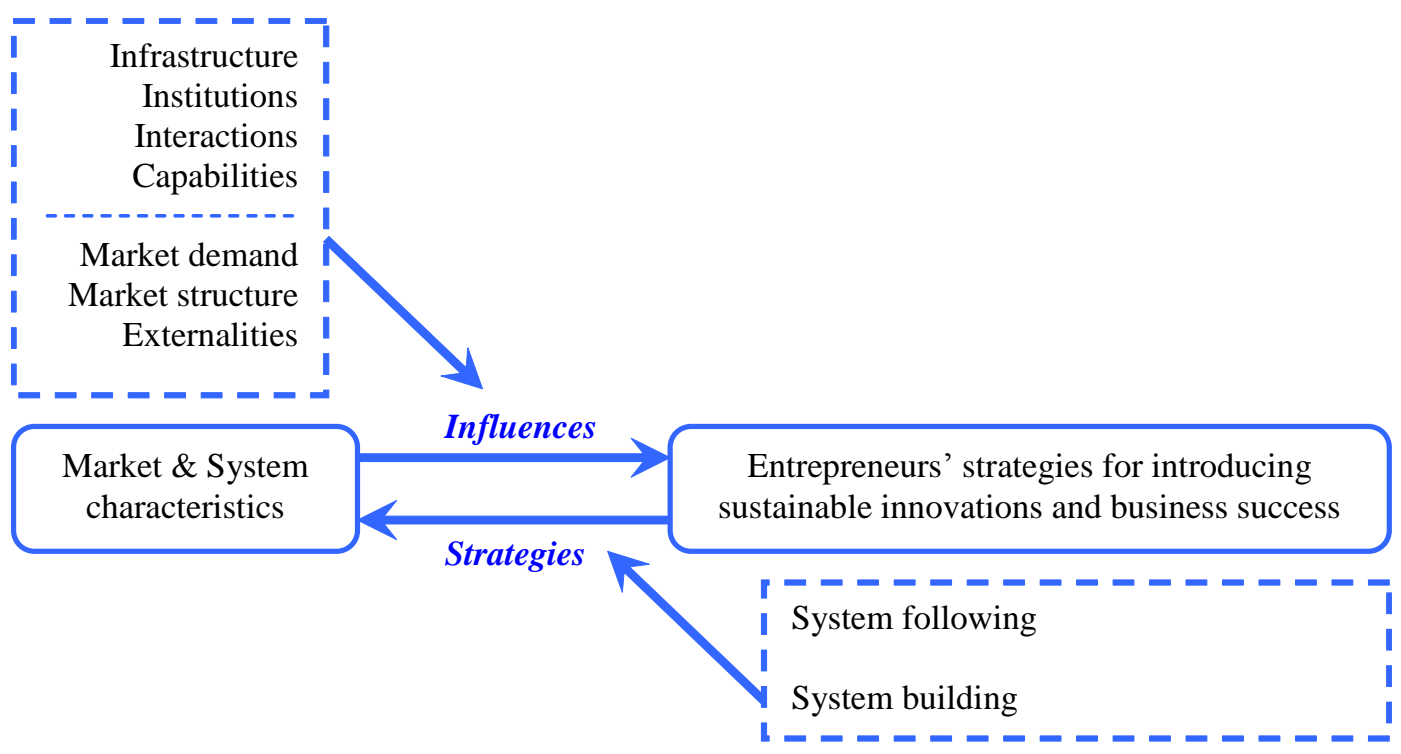




\section{Results}

As discussed briefly in the introduction, the Dutch construction industry is being pushed towards sustainability by e.g., government legislation. There are also encouraging forces though such as subsidy schemes that stimulate sustainable innovation in the energy sector [6] and motivate entrepreneurs to exploit the opportunities that arise out of this. From the interviews it also becomes clear that there is increasingly a market pull: mainly on the side of the commercial developments (offices), clients ask for sustainable solutions as they can reduce exploitation costs and improve their image. Whereas these are the most visible influences in the entrepreneurs' environment, we will next discuss which influences were considered especially important by the entrepreneurs, and which strategies they use to either challenge 'the system' or use it to their advantage. We will start with explaining how we distinguished between the system building and system following entrepreneurs and after that explain how their strategic actions differed.

\subsection{Two Strategies for Entrepreneurship in Sustainable Innovations}

During the interviews we recognized the 'system following entrepreneurs' as entrepreneurs that connect to current actors and institutions in order to introduce and diffuse sustainable innovations. We also saw confirmed that the group of 'system building entrepreneurs' had an entirely different business approach. This last group we saw, aimed to build new network relationships next to the existing system, and tried to create new institutions for the introduction and diffusion of their sustainable innovations. All in all they seemed to really try to build new systems in which other rules of the game applied and where other players were involved. These actors consciously do not want to operate in, or co-operate with, the 'old' system as they feel they have to compete with them to create something new. Often these actors are the 'frontrunners' of the sector that have a long-term vision and usually longer pay-back times of their innovations.

We will explain how these different entrepreneurs were influenced by the system and market context in which they were operating, and how they developed their system building or following strategies to deal with these influences. Not all characteristics will be discussed, as not all of them came up as equally important in the interviews. As explained in the method section, the results do not cover all aspects of the theoretical framework as we made use of open interviews. Whereas this is a drawback for the completeness of the discussion, it enabled us to get a more in-depth understanding of the strategies that the entrepreneurs used and the underlying beliefs for choosing these strategies. This in-depth insight we could not have been achieved, within the time-frame of this research, when we would have covered all aspects of the framework.

\subsection{Market and System Characteristics and Entrepreneurial Strategies of Coping with Them}

Below we will discuss the various influences that the entrepreneurs experienced, and their way of responding to these challenges. 


\subsubsection{Infrastructure}

Infrastructure plays a role in the implementation of various new products as current infrastructures in houses and offices are based on the 'old' paradigm of one central grid for electricity and water, and individual end-users that use and do not produce. In the 'new' paradigm the users can also become producers and the water and electricity grid can become more de-centralized. In practice, the entrepreneurs were stumbling into problems with the implementation of their products that enable this switch. For example, one entrepreneur that sells an electricity switch board that allows households to share electricity amongst them, stumbled into the problem that houses are and have to remain separate units in the current system. Related to this electricity problem is the uncertainty in The Netherlands about the 'feed-in' tariffs as there are no clear cut plans of regulations in this field.

Table 3. System influences and strategic reactions of system following and system building entrepreneurs.

\begin{tabular}{|c|c|c|}
\hline & System following entrepreneurs & System building entrepreneurs \\
\hline $\begin{array}{c}\text { Network } \\
\text { interactions }\end{array}$ & $\begin{array}{l}\text { They 'jump on the bandwagon' of } \\
\text { incumbent firms to use their access to } \\
\text { markets. They collaborate with vested } \\
\text { interests. }\end{array}$ & $\begin{array}{l}\text { They create a new network of willing players } \\
\text { outside of the vested interests. } \\
\text { Feel cooperation with vested interests is } \\
\text { counterproductive. }\end{array}$ \\
\hline Institutions & $\begin{array}{l}\text { Hard Rules and regulations provide } \\
\text { impulse for sustainable innovations as } \\
\text { large firms (to which they supply) are } \\
\text { pushed towards sustainability } \\
\text { Soft They adjust to current cultures, } \\
\text { norms and values as products 'sell on } \\
\text { accepted criteria as price and comfort'. } \\
\text { Sustainability is not put forward if it } \\
\text { clashes with common beliefs. }\end{array}$ & $\begin{array}{l}\text { Hard They are 'ahead of the game': find that } \\
\text { most regulations are barriers for innovation } \\
\text { and voluntarily set new standards. } \\
\text { Soft Sustainable norms and values } \\
\text { are emphasized to legitimize their sustainable } \\
\text { innovation. They persuade others to change } \\
\text { their mindsets and behaviours on } \\
\text { sustainability. }\end{array}$ \\
\hline Capabilities & $\begin{array}{l}\text { Enough capabilities in-house and good } \\
\text { access to knowledge suppliers. They } \\
\text { wait for technologies to prove } \\
\text { themselves commercially so they can } \\
\text { adopt it. }\end{array}$ & $\begin{array}{l}\text { They actively develop technologies, for which } \\
\text { they have enough capabilities, as they see } \\
\text { technology as an important driver for } \\
\text { innovation. Their relationships with } \\
\text { knowledge providers are a stimulus for this. }\end{array}$ \\
\hline $\begin{array}{l}\text { Market } \\
\text { demand }\end{array}$ & $\begin{array}{l}\text { There is enough demand for sustainable } \\
\text { products. They try to reach this market } \\
\text { through existing channels and with } \\
\text { proven technologies. }\end{array}$ & $\begin{array}{l}\text { They try to create new demand by informing, } \\
\text { demonstrating etc. They miss lead actors, e.g., } \\
\text { the government that demands high quality so } \\
\text { that new solutions can prove themselves (also } \\
\text { in demonstration projects) }\end{array}$ \\
\hline $\begin{array}{c}\text { Market } \\
\text { structure }\end{array}$ & $\begin{array}{l}\text { There is a small group of actors that } \\
\text { dominates construction industry. They } \\
\text { 'use' the dominant energy players as } \\
\text { clients and distribution channels. }\end{array}$ & $\begin{array}{l}\text { The market is 'locked' by a few very dominant } \\
\text { and conservative actors. They try to challenge } \\
\text { this existing power coalition by creating } \\
\text { networks of new players. }\end{array}$ \\
\hline
\end{tabular}


Other such problems are the use of rain water for domestic usage. In the past mistakes were made by installers which caused 'grey' water to mix with drinking water. As a result, regulations were made more stringent on using grey water for e.g., toilets and washing machines, making the introduction on greener technologies in this field more difficult.

As the entrepreneurs did not have clear strategies to change this, we did not include the category infrastructure in the analytical framework. It remains an important category though as all but 1 of the entrepreneurs believe that the future infrastructure will consist of a two-way energy grid and the realization of such a grid is essential to the viability of their business i.e., their business are build on the assumption of what the future infrastructure will look like!

\subsubsection{Institutions}

Hard institutions: Specifically in the field of regulative institutions, the interviewed entrepreneurs mention strong coercive pressures mainly due to the rules and regulations from the government. By the system following entrepreneurs, these rules and regulations are seen as a driver for sustainable innovations, whereas the system builders see it as a barrier. The followers see it as a driver for large incumbent firms to push them towards sustainability (such as energy labels and energy performance standards). Indirectly this creates a demand for entrepreneurs that supply innovative sustainable solutions to these large players. The system builders, to the contrary, experience regulation as a barrier to innovation as they try to introduce solutions that are:

'ahead of current standards and requirements' or

'introduce illegal innovations, because the government is too slow with adapting the regulations'

A problem to all is that is there is (a) a lack of standardization of policies and regulations in innovation and sustainability and, (b) too little coordination between the national, regional and local governmental levels. For instance, national and local rules on planning regulation differ, and regulations conflict each other in their implementation.

Here we conclude that rules and regulations can be a strong stimulus for innovation if applied in a consistent way and without too much 'red tape'. Rules and regulations provide a clear direction and enables entrepreneurs to define (future) business opportunities and make investment decisions accordingly.

Soft institutions: An important barrier to the adoption of sustainable innovations as mentioned by entrepreneurs resides in the minds of people or in their norms and values, and the culture within the industry. Many entrepreneurs are of the opinion that it is not yet 'normal' to use sustainable innovations in constructions and houses. One phrases it as 'people first need to grasp the concept of sustainability in their mind'. The required change not only includes the products and processes, but the whole value chain. However, this change is difficult. Some entrepreneurs state that actors around them fear innovation, they rather stay within the old, safe routine: Many actors...:

'have prejudices against sustainable innovations'

'are reluctant to try something new'

'are unwilling to implement sustainable innovations' 
The common belief is that sustainability costs money, that sustainable innovations don't work (well) and that they increase risk and complexity.

Mainly the installers are considered 'a very difficult hurdle to take' in introducing new technologies. This is a large problem as they have the most direct link to the end-users (both offices and houses) but refuse to change their working routines.

The second group of actors that have not got a mindset in which sustainability plays a role, are the investors. Entrepreneurs describe how they are always searching for investors but that these:

'look at profitability on the short term'

'are more reluctant when investing in sustainability'

A third actor that is considered a barrier for a culture change towards a more sustainable industry is the national government. Respondents state that the government does not adequately built a culture, norms, values, or a long-term vision that supports sustainability in general, and in the construction industry in specific:

'it does not clearly indicate a direction for progress of society'

'the government does not stick to the choices they make. This short-term behavior coupled with major political changes every 4 years is hurting the national reliability and stability'

'the government should worry about vision and the long-term, then I can start worrying about my short-term survival'

Entrepreneurs mention Al Gore as a prime example how the creation of awareness stimulates business and express the wish that national governments take a similar clear stand as this provides a long term planning horizon and legitimacy for their businesses.

We can hence conclude that soft institutions play a large role in the creation of markets and opportunities for entrepreneurs and that this function is direly missed in the Dutch construction sector. Here lies a large opportunity for the government and industry associations.

\subsubsection{Interaction}

Strong network failure: Another strong barrier to sustainable entrepreneurship mentioned by entrepreneurs is that of too strong collaboration between actors with vested interests. Projects in the built environment require inputs and effort from many stakeholders, from governments, businesses, owners, developers, suppliers etc., which makes cooperation and coordination crucial. The interactions between these actors are based on historic relations, are considered as rigid and fixed. Entrepreneurs mention that they cannot interact with them, because

'these stakeholders have been operating and cooperating in the same manner for decades'

'the whole system with all activities is based on rusted routines'

This creates strong network failures based and 'lock-in' in the sense that new knowledge, know-how and working routines will be hard to establish with these players and hence, the industry will tend to stay conservative

In the upcoming 'green' energy sector this is less the case since also large incumbent firms are forced to become more sustainable. However, these large energy companies have power and a strong 
energy lobby: 'they can afford to hire their own lobbyists'. Although the government aims to force these big companies to move towards sustainability through regulation and negotiation, the energy lobby can influence, stall or even prevent this. The entrepreneurs lack this power and argue that 'they are too small to have an influence'. System following entrepreneurs therefore connect with the vested interests and as a result mainly experience positive effects from the initiatives of energy companies - including increased media attention for sustainability, the ability to participate with large players in large projects, gaining access to existing markets and gaining access to higher governments.

System building entrepreneurs, to the contrary, cooperate outside of the vested interests and experience more opposing effects from incumbent firms, such as the delaying of sustainable investments and lobbying to halt new sustainability regulations. System building entrepreneurs argue that energy companies have no real incentive for reducing energy consumption or for promoting sustainable energy as they earn their money with the 'old' paradigm in which selling more is better. As such they are claimed to have:

'no clean motives'

'conflict of interests'

'do not run forward in the field of sustainability'

We can hence conclude that established practices between established actors forms a barrier for innovation for entrepreneurs. The system building entrepreneurs tackle this issue by establishing their own (competing) networks, whereas the system followers jump on the bandwagon of the large players as rules and regulations push them forwards to sustainability.

\subsubsection{Capabilities}

Technological knowledge and know-how: Technology, in the form of technological knowledge and development, was mentioned by most of the entrepreneurs as being an important enabling factor, but all of them emphasized that 'there are other factors that eventually make the difference' for successfully developing sustainable innovations. There were some differences between the building and following entrepreneurs: whereas the reactive ones feel they are waiting for the technology to 'prove itself':

'the technology is not yet ready and needs further development before we can proceed'

The system building entrepreneurs emphasize that the technological developments underlying their innovations are:

'essential for staying competitive'

'make our existence today possible'

Also, these entrepreneurs emphasize the role of knowledge providers in this process:

'the availability of technological knowledge providers forms the foundation of our existence'

Hence we can conclude that technology is important, but is not a hindering factor for innovation. The actors either have capabilities in-house, or know very well where to get it when they need it. 


\subsubsection{Market demand}

Quantity of demand: All entrepreneurs mention that there is a small, but growing demand for sustainable technical solutions in the construction industry. In the offices market this demand is more developed as the future user is more involved in the design and development of the buildings, and sees clear advantages in a sustainable office because of the positive effects of a reduced energy bill and a better image for the company. In domestic housing the link to the final user is more distant and users are more interested in common characteristics as comfort and price. Still, there is a clearly a growing demand for sustainable solutions as end-users want to contribute to a more sustainable world and want to increase their independency of central providers as a reaction on fluctuating (and feared increasing) energy and water prices. The entrepreneurs all are convinced of the market potential.

Quality of demand: In the current state of the art in the construction industry, demand is still very much on price. In many sectors of the construction industry, tendering procedures decide who will get the job. The result of these purchasing processes is that temporary coalitions between price fighters prevail over longer term strategic partnerships that strive for quality and innovation. Common sense is that (semi) government bodies should play the role of 'lead customer' in creating quality demand. However, these bodies are also subject to national and European legislation on procurement procedures.

Here we conclude that it is mainly the lack of quality in the demand that hinders new and better technologies to be introduced. There is a strong need for lead customers (e.g., the government) and lead markets (e.g., Dutch cooperatives for social housing).

\subsubsection{Market structure}

Market power: All the interviewed entrepreneurs indicate that in the construction industry, a few large players occupy the strong and powerful positions within the construction networks and seek to maintain power and control in the sector' as this increases their profits. The whole supply chain, up to the contacts with the customers, is dominated by these large players. The strong and closed networks in the construction industry are considered limiting for the possibilities for entrance of innovative entrepreneurs, since they feel that there is

'little room for outsiders to enter the competition of the industry'

The entrepreneurs mention that they have to fight them in order to gain a position and power and to successfully introduce their sustainable innovations. They also emphasize that change in the industry is difficult to achieve because many different stakeholders have to be facing in the same direction to try something new, and there can easily be

\section{'just one stakeholder that veto's the implementation'}

And if the entrepreneurs do find a way in to establish a position in the industry, often they remain dominated by a large partner or a more powerful supplier who can effectively control the small entrepreneur due to it's power over resources or market access. 
Entry costs are not considered a real problem: Although almost all sustainable innovations require initial investments, all sustainable innovations eventually pay-back economically within 1 to sometimes 15 years. All companies in this research were actively focused on contributing to sustainability, and have experienced growth in recent years in terms of turnover and employees (despite the crisis!). This confirms the proposition from the literature that sustainability and profit go together: entrepreneurs are indeed able to reconcile economic growth with a contribution to sustainability.

\section{Conclusions}

With regards to the influences from the context we can conclude that the most important drivers for sustainable innovation were the general public awareness of sustainability after Al Gore's plea for sustainability, and the entrepreneurs' faith in the future of sustainable technologies, which is supported by the fact that they prove to be able to get sustainable profits out of their businesses. The most important barriers that were distinguished on the basis of the market and system failure framework were the:

- beliefs and old routines that keep actors 'imprisoned' in the old paradigm (soft institutions),

- rules and regulations which were considered to lack long-term vision, clarity, coherence and consistency, making entrepreneurial strategy and action difficult,

- strong market dominance of incumbent firms in the construction industry that blocks the entry of new actors, products and processes, and practices,

- closed network linkages between incumbent firms with as a result to keep everything as it was, and provide no room for new information, learning, or changing of habits.

We found that the entrepreneurs seem to make a very conscious choice in dealing with these barriers, based on their interpretation of to what extent they can change the status quo, and to what extent they can either benefit or suffer from engaging into close relationship with the vested interests of the incumbent firms. An important contribution of our research is that we distinguish between different types of entrepreneurs: Whereas previous research mainly described strategies of resistance to environmental pressures [20], our findings illustrate how entrepreneurs are co-creators of their own environments by actively building networks, anticipating future laws and regulations and infrastructures, and influencing believes: the system building entrepreneurs. We also recognize though that both system building and following entrepreneurs are innovative and that both contribute to the transition towards sustainability, albeit in different ways. System following entrepreneurs are entrepreneurs for which the introduction and diffusion of sustainable innovations does not coincide with large changes in the system context. Although all entrepreneurs very much depend on changes in the system for the successful introduction and diffusion of their innovations, this type of entrepreneur is not the one initiating systemic changes, because they believe they 'simply can't change the system themselves'. Although they can unmistakably make a contribution to the transition in the sector by pushing other actors towards sustainability the system following entrepreneurs do not feel they should be the protagonists of systemic change, they rather use the system for achieving their business goals. On the contrary, for system building entrepreneurs, introducing and diffusing sustainable innovations 
coincides with actively creating changes in the system context. System building entrepreneurs aim to create a new system: they try to create new networks of willing actors in which new rules apply (e.g., buy and sell on other criteria) and with those networks they want to challenge the status quo. They aim to create a 'young, growing forest with many small innovative trees' to develop a range of sustainable innovations that compete with the 'unsustainable old forest'. System building entrepreneurs therefore have to have long planning horizons, and work towards realizing a future that for now only exists in their opportunity and ideology driven minds. That they are no dreamers in doing so is proven by the fact that they have good running business with their sustainable products.

All in all we conclude that in the construction industry there are many reasons to invest in sustainable solutions. Whereas the industry worldwide has a reputation to be conservative and unsustainable, there are new players that aim to push the industry towards sustainability. This article has looked into the drivers and barriers such entrepreneurs face, and the strategies they use to challenge the status quo and make their business successful. We found that becoming a sustainable entrepreneur does not mean one has to challenge the status quo. There are more routes then the attack, and both routes can be successful and contribute towards sustainability.

\section{Discussion and Notes for Further Research}

The contribution of this research of three-fold: First, we have contributed to the field of sustainable entrepreneurship and the understanding of innovation systems and transitions by introducing the Market and System Failure Framework for analyzing the markets and systems entrepreneurs operate in. This analytical framework offers clear guidance for analyzing a system and pin-pointing the drivers and bottlenecks for innovation. By doing this, also clear corrective action can be identified, in conjunctions with the actors that could undertake such actions. In this research we have focused on entrepreneurs, but the research could be repeated by e.g., interviewing government representatives or academics to get their view on the system's functioning. To get a complete overview of a system, ideally one would want to include all actor groups in such an analysis. The introduction of the analytical framework is the first step in this development.

Second, we contributed to the micro-level understanding of the interaction between the 'system' and the actors, being the entrepreneurs. Whereas many system analyses focus on the meso-level and long term changes, we choose to focus on the beliefs, strategies and actions of the entrepreneurs which we believe will possibly co-shape future system states. This understanding is important to open up the 'black box' of system change: the system is not a given, but is co-create by the actors that are in it. Some actors will naturally be more inclined to keeping things as they are (e.g., the powerful incumbents). It has been interesting to see how actors that do want to change the status quo deal with pressures towards change and those directed towards the status quo.

Third, we have contributed to the insights on sustainable entrepreneurship by distinguishing between system following and system building entrepreneurs. In the future it will be interesting to see whether we can develop this theoretical work further by refining this framework to include individual and collective entrepreneurial strategies (as some things are so hard to change that they need concerted action), and by looking further into which strategic action are used to tackle which specific market or 
system failures (e.g., which strategies do entrepreneurs use to try to change the market structure, and which actors do they involve?).

Whereas our research is a first step towards a better insight into how entrepreneurs can contribute to the transition towards a more sustainable construction industry, and into the strategies they can use to change certain system and market characteristics, there is still much work to be done. First of all, a replication of this research would be very worth-while to get a more detailed insight into the strategies entrepreneurs use vis-à-vis all aspects as distinguished in the theoretical framework. This would enable us to examine whether entrepreneurs consider it possible to e.g., influence the future set up of the infrastructure in their country, or to alter the market structures. Such insights would be very instructive for improving public-private collaborations, but also shed light on the question on which roles can be dealt with by the private sector, and which roles should be picked up by the government.

Such further elaboration of the interaction between the entrepreneurs' environment and their strategic reactions could lead to hypothesis concerning the nature of sustainable entrepreneurship; whereas the classical view on entrepreneurs was more the image of a lone inventor with a brilliant product, the sustainable entrepreneurs seem to have to be 'networkers' more than inventors. Their products might be less central to their entrepreneurial actions, it is the embedding of the products in new structures, and the reinvention of the game that seem to be key in these entrepreneurial processes: a game with new players, new relationships amongst them and new rules of the game.

\section{Acknowledgements}

This article is based on a joint research project between TNO Innovation and Environment and Utrecht University. I thank Sybrand de Boer: this article is based on his master thesis. I thank Lars Coenen, Felix Brandes and Fernando Diaz-Lopez for their constructive comments. All mistakes are mine.

\section{References and Notes}

1. Kemp, R. Technology and the transition to environmental sustainability-The problem of technological regime shifts. Futures 1994, 26, 1023-1046.

2. Geels, F.W. From sectoral systems of innovation to socio-technical systems-Insights about dynamics and change from sociology and institutional theory. Res. Policy 2004, 33, 897-920.

3. Spence, R.; Mulligan, H. Sustainable development and the construction industry. Habitat Int. 1995, 19, 279-292.

4. Ngowi, A.B. Creating competitive advantage by using environment-friendly building processes. Bldg. Environ. 2001, 36, 291-298.

5. World Commission on Environment and Development (WCED). Our Common Future; Oxford University Press: Oxford, UK, 1987.

6. Werkplan Nederland Ondernemend Innovatieland-Maatschappelijke Vraagstukken Oplossen Door Innovatie; Ministerie van Economische Zaken: Den Haag, The Netherlands, 2007. 
7. Hekkert, M.P.; Suurs, R.A.A.; Negro, S.O.; Kuhlmann, S.; Smits, R. Functions of innovation systems: A new approach for analysing technological change. Technol. Forecast. Soc. Change 2007, 74, 413-432.

8. Charles, F.; Bieri, A.; Paleocrassas, Y. Innovation - The Pathway to Threefold Sustainability; MIT Center for Technology, Policy, and Industrial Development (CTPID): Cambridge, MA, USA, 2001; pp. 233-274.

9. Cohen, B.; Winn, M.I. Market imperfections, opportunity and sustainable entrepreneurship. J. Bus. Venturing 2007, 22, 29-49.

10. Micro-Foundations for Innovation Policy; Nooteboom, B., Stam, E., Eds.; Amsterdam University Press: Amsterdam, The Netherlands, 2008.

11. Garud, R.; Karnøe, P. Bricolage versus breakthrough: Distributed and embedded agency in technology entrepreneurship. Res. Policy 2003, 32, 277-300.

12. Garud, R.; Karnøe, P. Path creation as a process of mindful deviation. In Path Dependence and Creation; Garud, R., Karnøe, P., Eds.; Lawrence Erlbaum Associates: New York, NY, USA, 2001; pp. 1-38.

13. Jacobsson, S. Universities and industrial transformation: An interpretative and selective literature study with special emphasis on Sweden. Sci. Public Policy 2002, 29, 345-365.

14. Dimaggio, P.J.; Powell, W.W. The iron cage revisited-Institutional isomorphism and collective rationality in organizational fields. Amer. Sociol. Rev. 1983, 48, 147-160.

15. Edwards, J.R. Problems with the use of profile similarity indexes in the study of congruence in organizational research. Pers. Psychol. 1993, 46, 641-665.

16. Edquist, C. Systems of National Innovation; Oxford University Press: Oxford, UK, 2005.

17. Markard, J.; Truffer, B. Technological innovation systems and the multi-level perspective: Towards an integrated framework. Res. Policy 2008, 37, 596-615.

18. Leca, B.; Battilana, J.; Boxenbaum, E. Agency and Institutions: A Review of Institutional Entrepreneurship; HBS Working Paper 08-096; Harvard Business School: Boston, MA, USA, 2008.

19. Klein Woolthuis, R.J.A.; Lankhuizen, M.; Gilsing, V. A system failure framework for innovation policy design. Technovation 2005, 25, 609-619.

20. Oliver, C. Strategic responses to institutional processes. Acad. Manage. Rev. 1991, 16, 145-179.

21. Lepoutre, J. Proactive Environmental Strategies in Small Businesses: Resources, Institutions and Dynamic Capabilities; University of Gent: Gent, Belgium, 2008.

22. Aragon-Correa, J.A.; Sharma, S. A contingent resource-based view of proactive corporate environmental strategy. Acad. Manage. Rev. 2003, 28, 71-88.

23. Sharma, S.; Henriques, I. Stakeholder influences on sustainability practices in the Canadian forest products industry. Strateg. Manage. J. 2005, 26, 159-180.

24. Yin, R. Case Study Research, 3rd ed.; Sage Publications: Thousand Oaks, CA, USA, 2003.

(C) 2010 by the authors; licensee Molecular Diversity Preservation International, Basel, Switzerland. This article is an open-access article distributed under the terms and conditions of the Creative Commons Attribution license (http://creativecommons.org/licenses/by/3.0/). 